\title{
Recent developments in genital herpes
}

Isto $\mathrm{N}$ THIS ADULT INFECTIOUS DISEASE NOTES IMPORTANT OBservations regarding genital herpes simplex virus (HSV) infections which have been published since 1989 are reviewed.

- The seroprevalence of HSV-2 antibodies reported in adults living in the United States was $16.4 \%$. This figure is remarkably similar to the seroprevalence reported from Toronto, Ontario at a similar time (2). In both studies, seroprevalence rates were approximately $40 \%$ higher in women than in men $(1,2)$. In the American study, infection rates were three times higher in blacks than whites (1). The seroprevalence approaches 50\% in sexually transmitted diseases clinic attendees (3).

- Most HSV-2 seropositive individuals are unaware of a diagnosis of genital herpes (3-5). However. among women, up to $50 \%$ will develop recognizable genital lesions within a period of five months (5).

- Asymptomatic shedding of HSV has been studies repeatedly in pregnant women. It is now clear that such shedding occurs in both men and nonpregnant women (6). Studies from the National Institutes of Health in the United States have found that symptomatic shedding occurs at a rate of eight days per 1000, and this rate does not differ substantially between men and women. However, the rate of asymptomatic shedding may have underestimated because culture swabs were refrigerated for up to three days prior to inoculation of cell cultures in that study.

- Although daily acylovir therapy markedly reduces the number of recurrences of genital herpes (by about $75 \%$ ) acylovir does not reduce asymptomatic shedding of HSV (6).

- Sexual transmission occurs more commonly from an asymptomatic source patient than from a symptomatic patient (7).

- As with other sexually transmitted diseases, HSV-2 is transmitted more effectively from male to female than female to male (7).
- The prior presence of HSV-1 antibodies in serum clearly reduces the chances of sexual transmission of HSV-2 (7), however, HSV-1 antibody does not appear to prevent neonatal transmission of HSV-2 (8).

- Approximately 10\% of pregnant women are both HSV-2 seronegative and have HSV-2 seropositive sexual partners (8). These women are clearly at risk of primary HSV-2 infection during pregnancy which is associated with a 40 to $50 \%$ rate of neonatal herpes infection.

- Approximately one-third of women who are asymptomatic shedders of HSV at parturition have primary HSV infections and thus are at high risk of neonatal transmission (4).

- After primary genital HSV-2 infection, asymptomatic shedding of virus is common for a period of three months (9).

- Increasing data supporting the safety of acyclovir during pregnancy have now been accrued (10).

These observations add substantially to our understanding of genital herpes and its sexual and neonatal transmission. The high prevalence of HSV-2 infections combined with the recognition of asymptomatic viral shedding as the major route of sexual transmission is yet another reason that safer sex practices must be promoted. Unfortunately, these studies do not significantly change the approach tot he diagnosis and management of such infections. Guidelines for preven tion of perinatal transmission were revised in 1987. recommending the abandonment of weekly genital cultures in patients with a positive history of genital herpes since: this does not identify the majority of patients with genital HSV infection; this has not been shown to predict viral shedding at labour and the risk of perinatal transmission in recurrent genital herpes is extremely low (11). Similar guidelines have been in endorsed in Canada (12). Unfortunately, there is still no reliable strategy to prevent most cases of neonatal herpes infection. However, many need less cesarean deliveries can 
be avoided and effective therapy is available for the approximately one in 2000 infants who develop neonatal herpes

\section{REFERENCES}

1. Johnson RE, Nahmias AJ, Magder LS, Lee FK, Brooks CA. Snowden CB. A seroepidemiologic survey of the prevalence of herpes simplex virus type 2 infection in the United States. N Engl J Med 1989:321:7-12.

2. Stavrasky Km, Rawls WE, Chiavetta J, Donner AP, Wanklin JM. Sexual and socioeconomic factors affecting the risk of past infections with herpes simplex virus type 2. Am J Epidemiol 1983; 1 18:109-21.

3. Koutsky LA, Stevens CE, Holmes KK, et al. Underdiagnosis of genital herpes by current clinical and viral-isolation procedures. N Engl J Med 1992;326:1533-9.

4. Brown ZA, Benedetti J, Ashley R, et al. Neonatal herpes simplex virus infection in relation to asymptomatic maternal infection at the time of labor. N Engl J Med 1991:324:1247-52.

5. Langenberg A, Benedetti J, Jenkins J, Ashley R, Winter C, Corey L. Development of clinically recognizable genital lesions among women previously identified as having 'asymptomatic' herpes simplex virus type 2 infection. Ann Intern Med 1989:1 10:882-7.

6. Straus SE, Seidlin M, Takiff HE, et al. Effect of oral acyclovir treatment on symptomatic and asymptomatic virus shedding in recurrent genital herpes. Sex Transm Dis 1989;16:107-13.

7. Mertz GJ, Benedetti J, Ashley R, Selke SA, Corey L. Risk factors for the sexual transmission of genital herpes. Ann Intern Med 1992;116:197-201.

8. Kulhanjian JA, Soroush V, Au DS, et al. Identification of women at unsuspected risk of primary infection with herpes simplex virus type 2 during pregnancy. N Engl J Med 1992:326:916-20

9. Koelle DM, Benedetti J, Langenberg A, Corey L. Asymptomatic reactivation of herpes simplex virus in women after the first episode of genital herpes. Ann Intern Med 1992:1 16:433-8.

10. Andrews EB, Yankaskas BC, Cordero JF, Schoeffler K, Hampp S, the Acyclovir in Pregnancy Registry Advisory Committee. Acyclovir inpregnancy registry: Six years ${ }^{\circ}$ experience. Obstet Gynecol 1992:79:7-13.

11. Gibbs RS, Amstey MS, Sweet RL, Mead PB, Sever JL. Management of genital herpes inpregnancy. Obstet Gynecol 1988;71:779-80.

12. Infectious Diseases and Immunization Committee, CanadianPaediatric Society. Toward the rational management of herpes infection in pregnant women and their newborn infants. Can Med Assoc $J$ 1992;146:1557-60.

SD Shatran, MD, FRCPC

Edmonton, Alberta

JM Conly, MD, FRCPC

Saskatoon, Saskatchewan 


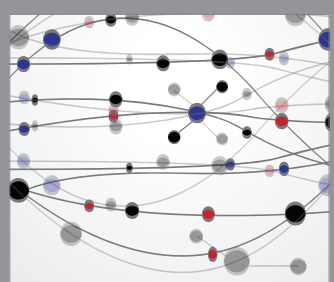

The Scientific World Journal
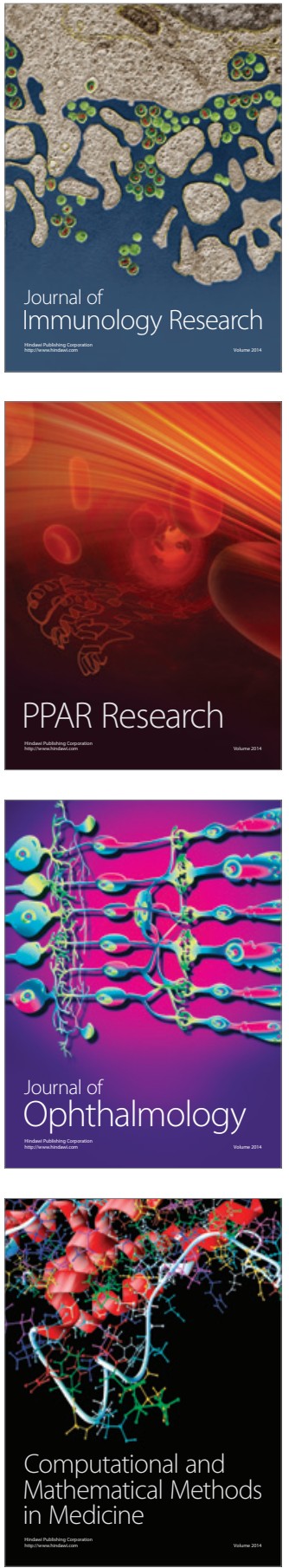

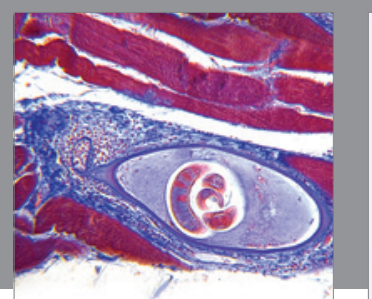

Gastroenterology Research and Practice

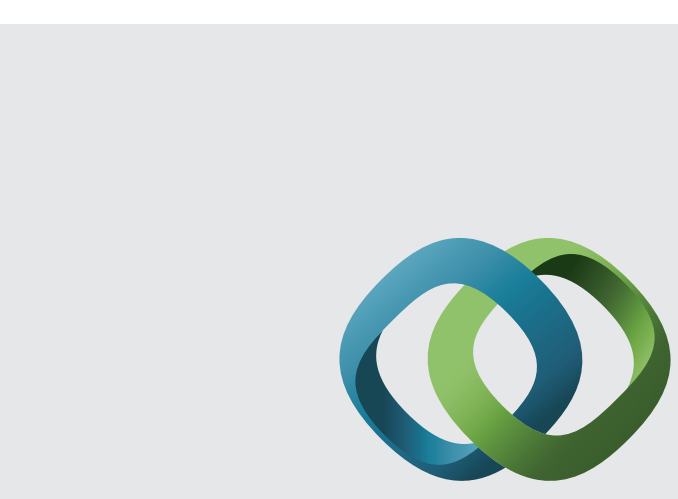

\section{Hindawi}

Submit your manuscripts at

http://www.hindawi.com
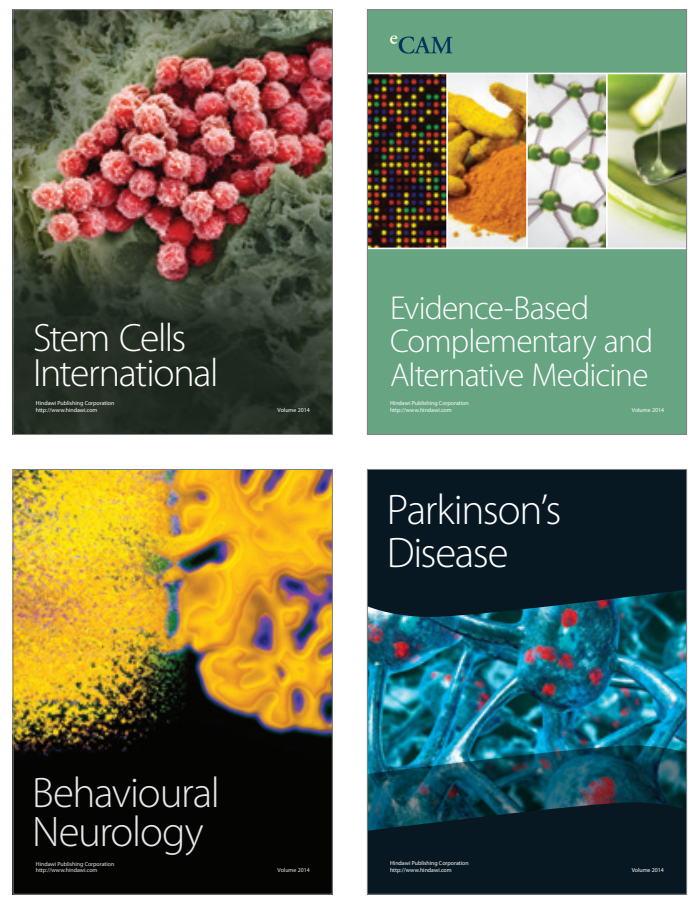
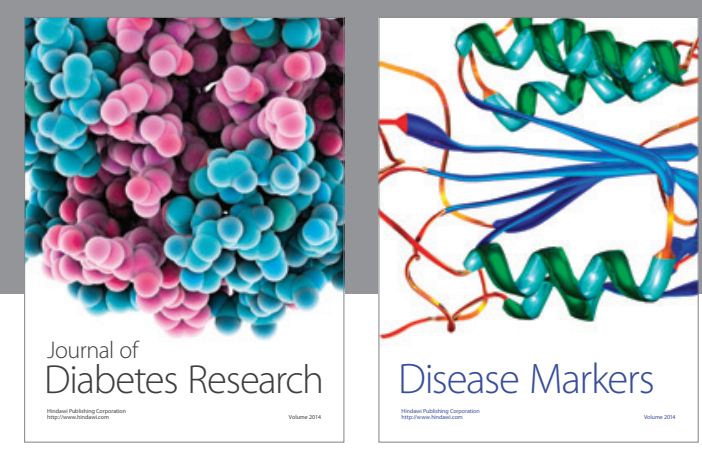

Disease Markers
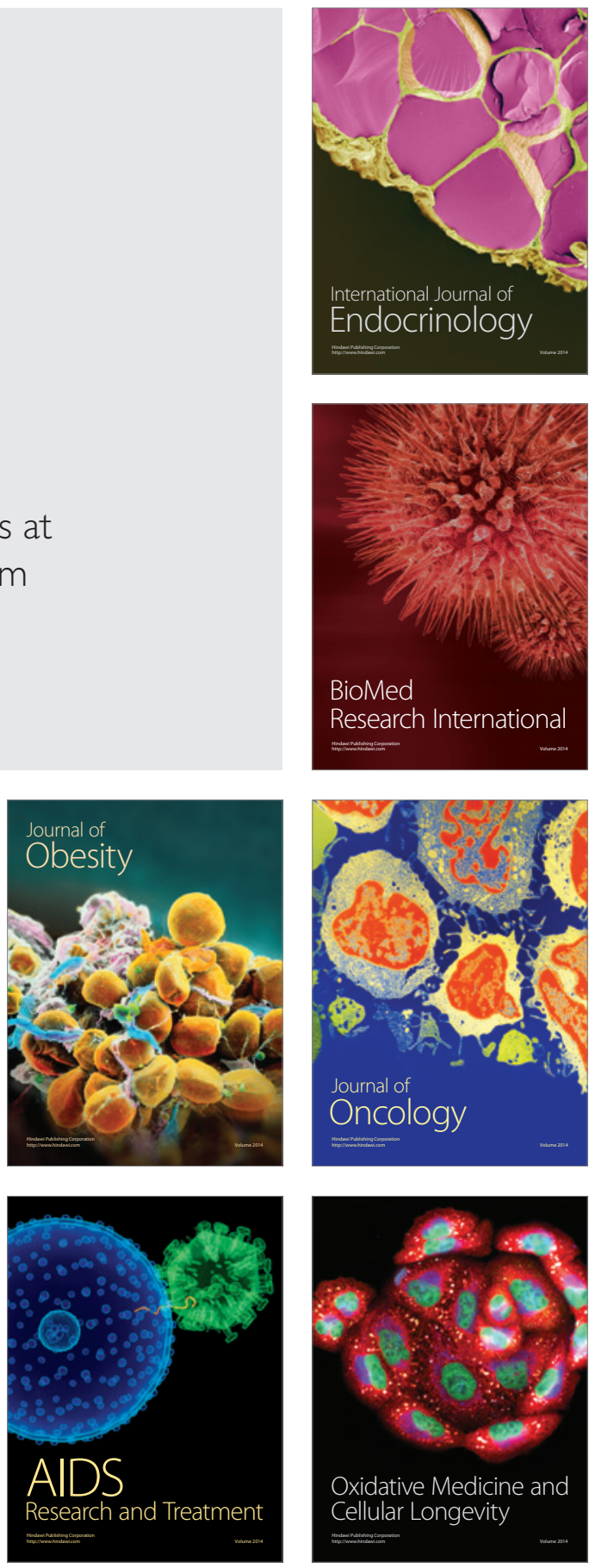